\title{
1 \\ Establishing the Platform: The Interwar Years
}

\begin{abstract}
When asked about the future of broadcasting Mrs. Couchman said she visualised it as a growing tree which would increasingly shelter all sorts of service to the people of our scattered Commonwealth, and which in conjunction with other great public services would have great influence in the future development of our national life. ${ }^{1}$
\end{abstract}

A dual system of public and commercial broadcasting is a hallmark of Australia's media landscape; however, this system was not in place until nearly a decade after the introduction of radio into the country. Originally, A-Class stations were not government run but rather funded through listener licence fees, while B-Class stations were privately funded. In this early period, both types of stations took seriously their responsibility to educate the public, and it was not until the 1930s that commercial radio's role as a domestic companion and entertainment medium became apparent. ${ }^{2}$

Public broadcasting finally arrived in Australia with the establishment of the Australian Broadcasting Commission (ABC) on 1 July 1932. ${ }^{3}$ It was governed by five commissioners, including one woman: May Couchman, president of the Australian Women's National League (AWNL), an organisation committed to non-labour politics and aligned with the United Australia Party, and vice-president of the National Council

1 Enid Baumberg, 'Mrs. Claude Couchman: Member of the Australian Broadcasting Commission', Sydney Mail, 29 June 1932, 8.

2 Lesley Johnson, The Unseen Voice: A Cultural History of Australian Radio (London: Routledge, 1988), 1-2, 202-04.

3 K. S. Inglis, This is the ABC: The Australian Broadcasting Commission, 1932-1983 (Carlton, Vic.: Melbourne University Press, 1983), 5. 
of Women (NCW). ${ }^{4}$ As the only woman commissioner on the $\mathrm{ABC}$ Board in the 1930s, she was the 'only woman with any power to affect $\mathrm{ABC}$ programs' and used her position to push for better quality talks for women to lift them 'from the atmosphere of the gas stove and ironing board'. 5 Couchman believed that broadcasting had significant power to improve society. The above quotation, taken from an interview with the Sydney Mail upon her appointment to the commission, demonstrates the centrality of public service to her conceptualisation of the role of broadcasting. ${ }^{6}$ This view was influenced by her role as a leading figure in a number of women's organisations that agitated for greater female participation in politics and society. ${ }^{7}$ Couchman argued that women had a civic duty to perform and that 'women have before them countless opportunities of rendering a continually growing contribution to the solution of our national problems'. ${ }^{8}$ These two aims-the social potential of broadcasting and women's civic duty-were central elements that shaped the development of women's broadcasting as a key platform for women to contribute to the public sphere in the interwar years. The importance of radio to women's civic lives became so profound that, by 1936, Portia Geach, president and founder of the Housewives Association (HA) of New South Wales, could claim that radio had 'opened up an enormous field for women'. ${ }^{\text {? }}$

This chapter examines women's broadcasting in the interwar years. During this formative period, a number of women came to believe that radio could affect a deep cultural change that would improve women's lives and their status in society. These women worked to establish the medium as one that could facilitate women's active participation in the public sphere. Their work was, in many ways, embedded within the broader activism of the period, a high point of the activist woman citizen due to a significant number of large and active women's organisations. ${ }^{10}$ During the 1930s, women broadcasters used radio to perform their civic duty of supporting

4 Judith Smart, 'Couchman, Dame Elizabeth May Ramsay (1876-1982)', Australian Dictionary of Biography (National Centre of Biography, The Australian National University, published first in hardcopy 2007), adb.anu.edu.au/biography/couchman-dame-elizabeth-may-ramsay-12359, accessed 26 February 2018.

5 Inglis, This is the $A B C, 32$.

6 Baumberg, 'Mrs. Claude Couchman'.

7 Smart, 'Couchman, Dame Elizabeth May Ramsay (1876-1982)'.

8 Baumberg, 'Mrs. Claude Couchman'.

9 'Radio Likes and Dislikes', Radio Pictorial of Australia, August 1936, 43-44.

10 Marilyn Lake, Getting Equal: The History of Australian Feminism (Sydney: Allen \& Unwin, 1999), 9. 
their communities by using sincerity and empathy in their broadcasts, by creating communities of women working together and by highlighting the importance of women's collective action. Feminists used broadcasting to assert women's right to financial independence to counterattacks on women workers within the context of high male unemployment. Professional women broadcasters exhibited the confidence, standing and expertise necessary to contribute to public debate, and, in doing so, further opened up the public sphere to women. While in this early period commercial radio presented the greatest opportunities for women to air their voices, Couchman's example shows that there were also growing opportunities at the $\mathrm{ABC}$.

\section{Women's Organisations in Interwar Australia}

The widely held notion of feminism as occurring in two 'waves'-the movements of the late nineteenth and early twentieth centuries and the 1960s and 1970s - has led to a characterisation of the interwar years as a dormant period for women's activism. In fact, this period was a high point for Australian feminism as many women's organisations were founded or expanded and the female 'activist citizen came into her own'. ${ }^{11}$ As we have seen, Couchman was a leading example of this activist citizen who developed a significant public profile from her senior roles in the AWNL and NCW. ${ }^{12}$ The NCW was an umbrella organisation that brought together a diverse range of women's organisations to give them greater clout in influencing political decision-making, including the AWNL, the Women's Service Guilds (WSG), the Feminist Club, the United Associations (UA), and Women's Non-Party Leagues in South Australia and Tasmania, along with professional women's organisations. Many of these organisations emphasised the commonalities of women's experiences that went beyond party politics, thereby constructing women as a collective with coherent and uniform political goals. ${ }^{13}$

11 Marilyn Lake, 'The Inviolable Woman: Feminist Conceptions of Citizenship in Australia, 19001945', Gender \& History 8, no. 2 (1996): 197-98.

12 Smart, 'Couchman, Dame Elizabeth May Ramsay (1876-1982)'.

13 Judith Smart, 'Christian Women and Changing Conceptions of Citizenship Rights and Responsibilities in Interwar Australia', in Citizenship, Women and Social Justice: International Historical Perspectives, ed. Joy Damousi and Katherine Ellinghaus (Melbourne: Department of History, University of Melbourne and the Australian Network for Research in Women's History, 1999), 190-92; Marian Quartly and Judith Smart, 'The Australian National Council of Women: Its Relations with Government to 1975', Australian Feminist Studies 29, no. 82 (2014), 352-53. 
Many feminists in this era argued that citizenship was the key to securing women's freedom from the violation of their bodies and their oppression at the hands of 'masculine tyrannies'. ${ }^{14}$ Citizenship rights would secure women's status as self-possessed individuals, and feminists campaigned for women's economic independence, child endowment and motherhood endowment to secure their freedom from male dominance. They constructed an ideal of maternal citizenship that was conceptualised 'as a two-way contract through which mothers would be paid for their service to the state: this was their citizen's right and would secure their economic independence'. ${ }^{15}$ The ideal of maternal citizenship, however, was also one that emphasised women's inherent difference as citizens due to their reproductive potential; in this way, feminists reinforced the status of women citizens as 'other' and constructed them as sharing common values and interests due to their sex. ${ }^{16}$

It was not only avowed feminists who advocated women's citizenship in the interwar years. There was also a significant rise in membership numbers of other types of women's organisations during the 1920s, such as the HA, the Country Women's Association, and the Women's Christian Temperance Union. These organisations sought to bring the 'well-run Christian home into community life' and, as such, they saw no contradiction in entering the public sphere to promote the home. ${ }^{17}$ Their view of using the principles of moral home management to improve the public sphere complicates any notion of the separation of public life from domestic life in this era. These women conceptualised good citizenship values as a way in which the feminised private sphere would improve the masculinised public sphere. ${ }^{18}$ If these women saw citizenship as crossing the divide between the private and the public, then radio, which also blurred the boundaries between them, was the ideal medium through which to articulate this feminised citizenship.

Interwar women's organisations provided middle-class women with an opportunity to actively engage in civic duties and to see themselves as active citizens, but these organisations also tended to emphasise particularly

14 Marilyn Lake, 'Personality, Individuality, Nationality: Feminist Conceptions of Citizenship 1902-1940', Australian Feminist Studies 19 (1994): 26.

15 Ibid., 25-28.

16 Lake, Getting Equal, 34.

17 Judith Smart, "For the Good That We Can Do": Cecilia Downing and Feminist Christian Citizenship', Australian Feminist Studies 19 (1994): 41.

18 Ibid., 39-45. 
feminised forms of citizenship. However, this does not explain why an increasing number of feminists agitated for equality with men in more typically masculine domains such as employment and politics. A number of these women broadcast their arguments for women's equality during women's sessions, and the increasing number of professional female announcers legitimised the place of women on the airwaves as informed citizens. In this way, radio became an important platform from which feminists could begin to break out of the strictures of maternal citizenship, and through their radio speech act as citizens by contributing to public debate and reaching out to other women.

\section{Broadcasting Feminism}

Interwar feminists recognised the potential of radio as a medium that they could use to speak directly to women and advocate a range of issues, including married women's nationality rights, women's right to careers and political representation, and women's legal rights. One 1930s radio program that featured these feminist messages was the Australian Women's Weekly's $(A W W)$ session, The Woman's Hour. Launched in June 1933 as a newspaper for women, the $A W W$ promoted a feminist agenda in its earliest years by offering a platform for a re-evaluation of women's role in society. ${ }^{19}$ Crucially, the magazine also 'gave Australian women a redefinition of Australianness that included them in it'. ${ }^{20}$ This reassessment of Australianness extended to broadcasting.

The $A W W$ s radio session was announced in the magazine on 24 February 1934. The program was promoted as something 'entirely new in women's radio sessions' that would extend the magazine's policy of giving women the best possible service in broadcasting. ${ }^{21}$ The sessions were to be overseen by feminist leader Linda Littlejohn, who also gave regular talks on the program, and presented by Dorothea Vautier, an announcer from New Zealand who had made a name for herself in the Sydney radio scene. The $A W W$ emphasised Vautier's outstanding experience and attractive voice-'one of the finest broadcasting voices in Australia'-

19 Denis O’Brien, The Weekly (Melbourne: Penguin Books Australia, 1982), 21.

20 Susan Sheridan et al., Who Was That Woman?: The Australian Women's Weekly in the Postwar Years (Sydney: UNSW Press, 2001), 4.

21 'The Women's Weekly Links Up with Station 2UW', Australian Women's Weekly, 24 February $1934,2$. 
which equipped her to take the helm of their women's sessions in $1934 .^{22}$ The choice of Vautier as the regular announcer for the session ensured that the feminist message was delivered by an ideal radio voice.

The radio program aimed to present the same popular content as the magazine, only every day. The session was launched at the $2 \mathrm{UW}$ studios on 26 February by feminist Jessie Street, Littlejohn's colleague in the UA. In her speech, Street articulated her perception of radio as a transformative medium for women, congratulating the directors of $2 \mathrm{UW}$ and the $A W W$ 'on their arrangement for a link-up, which she thought would do much to help Australian women realise their proper status in life'. ${ }^{23}$ The radio session would complement the magazine, enabling women to engage with its content every day and hear the voices of other women, which in turn would influence their own conceptualisations of their abilities, responsibilities and place in the world.

The drive to use the radio session to raise the feminist consciousness of women listeners had much to do with Littlejohn. She was one of the leading figures to promote radio's role in fostering women's citizenship in the interwar period, as she used her position and knowledge as a professional broadcaster to promote the feminist message. Born in Sydney in 1883, she had become well known in Sydney feminist circles by the 1920s, serving as an executive member of the NCW of New South Wales and the Feminist Club, founding the League of Women Voters in 1927 and co-founding the UA with Jessie Street in 1929. Littlejohn's broadcasting career was also prolific. ${ }^{24}$ She was a well-known and wellregarded broadcaster who worked for a range of stations including the BBC, 2UW, 2UE and 2GB. ${ }^{25}$ By the late 1920s, 'Littlejohn was participating in on-air debates and delivering radio talks about women's engagement in public life, such as the need for women jurors. ${ }^{26}$

22 Ibid.

23 '2UW's New Women's Sessions: Successful Opening at the New Studios', Australian Women's Weekly, 3 March 1934, 21.

24 Meredith Foley, 'Littlejohn, Emma Linda Palmer (1883-1949)', Australian Dictionary of Biography (National Centre of Biography, The Australian National University, published first in hardcopy 1986), adb.anu.edu.au/biography/littlejohn-emma-linda-palmer-7208, accessed 26 February 2018.

25 Ibid.; Lake, Getting Equal, 171.

26 Jeannine Baker, 'Woman to Woman: Australian Feminists' Embrace of Radio Broadcasting, 1930s-1950s', Australian Feminist Studies 31, no. 93 (2017): 298. 
During the early 1930s, Littlejohn became one of the most vocal advocates for women's equality with men-a shift away from the feminist focus on women's maternal difference as citizens that dominated the $1920 \mathrm{~s}^{27}$ It is notable that she was a leading figure in this rhetorical shift at the same time that she was regularly hosting a women's session on 2UW, as she was able to make use of her platform to spread her message and encourage other women to engage with ideas of equality and agitate for their rights. ${ }^{28}$ The active citizenship of feminist leaders like Littlejohn was often made possible by their independent incomes and domestic help. ${ }^{29}$ This was certainly true for Littlejohn, who was from a wealthy background that enabled her to take up many leadership positions with feminist organisations and travel extensively. Her radio work provided both a supplement to her income and, more importantly, a platform from which to promote her agenda and recruit new women to the cause. Littlejohn was a practised and eloquent speaker, a skillset she made use of to promote women's equality and model active citizenship on the air. ${ }^{30}$ In the $A W W$ Littlejohn was described as having 'many years of journalistic and broadcasting experience, which makes her eminently suitable for this work ${ }^{31}$ Radio was an ideal medium for Littlejohn, as she could utilise her polished speaking voice to directly address women listening in their homes. She was well suited to taking advantage of the opportunity offered by the new medium of radio to advocate the feminist cause.

Littlejohn had been associated with the $A W W$ since its inception, writing an article on the need for equal social rights between the sexes for the front page of the magazine's first issue. ${ }^{32}$ In 1934, she regularly wrote for the $A W W$ about the radio sessions and emphasised the potential of radio to improve women's position in society. In April 1934, for example, she argued that radio had enabled time-poor housewives to learn about a wide array of topics:

Actually it would be impossible to exaggerate what broadcasting has done and is doing for women, for there are women to-day who, amidst their multitudinous household tasks, their tennis, or

27 Lake, Getting Equal, 171.

28 'Personalities at 2UW', Broadcast Year Book and Radio Listeners' Annual, 1934, 106.

29 Lake, Getting Equal, 140.

30 Ibid., 171.

31 'The Women's Weekly Links Up with Station 2UW', 2.

32 Linda P. Littlejohn, 'Equal Social Rights for Sexes', Australian Women's Weekly, 10 June 1933, 1. 
their bridge, have time to discover for themselves the never-ending novelties in fashion, in cooking, in the wider range of world news, travel, books, or the newest music. ${ }^{33}$

In March 1934, she wrote of the 'close alliance' between radio and the press, as radio expanded on the news 'with special talks by experts on affairs of interest for which a newspaper could not spare the space'. ${ }^{34}$ This, in turn, resulted in a more educated populace. Through articles such as these, Littlejohn promoted her belief in radio's ability to expand women's horizons and worked to cement its role as a key tool for feminist activism.

From its inception, the UA used broadcasting in its publicity campaigns and encouraged its members 'to become proficient public communicators'. ${ }^{35}$ During this period, the organisation campaigned vociferously for equal rights for women including for the employment of married women teachers, married women's nationality rights, divorce law reform, equal pay, women's jury service and women's representation in government. ${ }^{36}$ These themes were reflected in the topics discussed on the $A W W$ 's sessions. The week of 10 March 1934, for example, featured a talk on needlework, several book reviews, a talk by Littlejohn on whether women should be employed in industry, a talk on advertising as a career for women, one on the music of other countries, and another on whether prosperity or adversity had the most influence on personality development. ${ }^{37}$ The week of 12 May 1934 featured talks on legal pitfalls for women, women and war, life in Russia, women under Christianity and news of women across the globe. ${ }^{38}$ Another feature of the program was its on-air debates between women and men on issues related to women's equality. These included debates on whether women should propose, whether women's work should be restricted to purely feminine avenues and whether wives should have salaries. ${ }^{39}$ Through talks such as these, the $A W W$ s radio sessions promoted a distinctively feminist agenda,

33 Linda P. Littlejohn, '2UW Highlights for Readers', Australian Women's Weekly, 28 April 1934, 5.

34 Linda P. Littlejohn, 'Radio and the Written Word: A Close Alliance', Australian Women's Weekly, 3 March 1934, 10.

35 Baker, 'Woman to Woman', 296.

36 Winifred Mitchell, 50 Years of Feminist Achievement: A History of the United Associations of Women (Sydney: United Associations of Women, 1979), 12-22.

37 'The Women's Weekly and 2UW', Australian Women's Weekly, 10 March 1934, 16.

38 '2UW Highlights for Readers', Australian Women's Weekly, 12 May 1934, 8.

39 '2UW Highlights for Readers', Australian Women's Weekly, 26 May 1934, 8; '2UW Highlights for Readers', Australian Women's Weekly, 23 June 1934, 7; '2UW Highlights for Readers', Australian Women's Weekly, 24 March 1934, 35. 
shaped as they were by Littlejohn and the UA. The eloquent voices of women who featured on the program, including Vautier and Littlejohn, gave the program a respectable veneer that helped to deliver their message of women's equality. The sessions provided a forum for women's voices to talk about feminist issues on daytime radio, which was a significant step in moving beyond the ideal of maternal citizenship towards a clearer recognition of the importance of formal equality between the sexes for women's ability to be fully fledged citizens.

Personal networks played a crucial role in getting a number of feminist voices on the air in the 1930s, as women like Littlejohn drew on their connections in various associations to fill the airtime on their shows with feminist messages. After moving from Perth to Sydney in 1931, Irene Greenwood joined the UA on a recommendation from Bessie Rischbieth, who she knew from her time in the Western Australian WSG. Greenwood recalled that Littlejohn and her UA co-founder Jessie Street enthusiastically inducted her into the organisation, promoting her to key roles in the public speaking and broadcasting committees. ${ }^{40}$ Littlejohn was a particularly strong influence on her, and Greenwood often filled in for Littlejohn on her women's sessions when she was out of town. ${ }^{41}$ Greenwood also often participated in the regular debates on the $A W W$ s sessions, including one in April 1934 on taxing unmarried men, and another in August 1934 on why women chose to marry. ${ }^{42}$ The example of Littlejohn and the $A W W s$ radio sessions demonstrates that broadcasting was a key way in which the shift in emphasis from highlighting women's difference as citizens to agitating for their equal rights with men was articulated by Australian feminists. The daily women's session carried the message of equality and aimed to foster regular engagement with feminist broadcasting. Feminists such as Littlejohn, Street and Greenwood believed that broadcasts could encourage women to think of themselves as equal citizens and become more active in movements for political, social and legislative change. They also claimed their own spaces within the media by demonstrating that women could intelligently contribute to public discourse.

$40 \mathrm{OH}$ 1094, Interview with Irene Greenwood, Feminist, 1 August 1982, State Library of Western Australia, Perth.

41 Kaye Murray, A Voice for Peace: The Spirit of Social Activist Irene Greenwood (1898-1992) (Perth: Kaye Murray Productions, 2005), 42.

42 2UW Highlights for Readers', Australian Women's Weekly, 25 August 1934, 8; '2UW Highlights for Readers', Australian Women’s Weekly, 21 April 1934, 22. 


\section{Raising the Status of the Housewife}

Radio broadcasts were embraced by a wide range of women's organisations to communicate with their members and to promote women's collective power as a political force. While many of these organisations did not adopt the feminist label, their work nevertheless places them within feminist activism. They recognised the role of radio as a tool that was especially well suited to raising the political consciousness of women in the home, even if they often focused on different issues in their broadcasts than more overt feminists such as Littlejohn.

The HA articulated a concept of women's citizenship based on Protestant Christian values that were secularised and practical, rather than overtly spiritual. It promoted women's domestic role in the language of 'modernity, efficiency, science and progress' - 'a language that claimed power, and this claim reinforced the many assertions of feminine citizenship that grew louder and stronger' in the interwar years. ${ }^{43}$

One of the most important reasons for the Victorian HA's rapid growth in 1937 and 1938 was the institution of 'radio broadcasts aimed at raising the public profile and status of the housewife. ${ }^{44}$ The 1936 annual report noted that the executive decided to begin broadcasting that year and acquired a morning session on commercial station $3 \mathrm{XY}$, as well as a weekly slot on Monday mornings on 3AW. The HA used the sessions to give reports of its activities to members. This endeavour was rewarded with a significant increase in membership applications, most notably from regional areas of the state. The HA also established a radio club, the Morning Tea Club, for its members. ${ }^{45}$

The HA was notable for its use of broadcasting to promote active citizenship to women in the home. Through their broadcasts they promoted an image of the civically engaged housewife who made problems such as the price of bread and milk into political issues. They also emphasised the importance of women acting collectively to improve women's lives. For example, the vice-president, Alice Speedie, gave a radio talk on equal pay for women in 1936. She argued that women were now achieving in a range of fields,

43 Judith Smart, 'A Mission to the Home: The Housewives Association, the Women's Christian Temperance Union and Protestant Christianity, 1920-1940', Australian Feminist Studies 13, no. 28 (1998): 216.

44 Ibid., 223.

45 'Housewives Association's Annual Report', Housewife, May 1936, 9. 
but that they 'should not be satisfied with the mere glory of attainment' and that they 'should not be denied the right to claim equal payment for the services they render, otherwise [their] claim to equality is a valueless one'. ${ }^{46}$ Further, she asserted that women needed to fight for equal pay, and should do so collectively:

I do not think that women are aware of the great power they hold, nor do they think as collectively as they should in the general interests of their sex. There are many women's Associations in our midst which naturally work for particular aims in politics, welfare, charity, etc., but none of them seem to advocate and work generally for the principles of women's equality ... If women thought and acted collectively the reproach could not lie on us, that with an equal franchise with men in the politics of the country, there is no single woman representative in our houses of legislature. ${ }^{47}$

Thus, for Speedie, collective action was the key to female emancipation. Her broadcast demonstrates the centrality of the advancement of women's equality to the HA's outlook, as well as the role of radio in promoting this concept to women in the home and encouraging them to become actively involved in the organisation.

Earlier in 1936, Mrs J. Salter Watts, then vice-president, gave a broadcast that examined women's responsibility to engage in civic activities through associations and charities. Watts argued that a woman's first responsibility was to look after her own family, but when a woman had sufficient help at home she had a responsibility to get involved with societies and charities. She argued that women proved their capacity for organisation during World War I, which brought out hitherto dormant talents. She did not 'approve of too much "Stay-at home" when we can do so much and help so many'. ${ }^{48}$ Cecilia Downing, senior vice-president, broadcast on the role of the HA as a nucleus of women's citizenship activity. She argued that:

The housewife's interest is not merely looking after the house as a place of residence, but she has a wider interest in the physical, moral, social and spiritual care of the home ... she is a citizen interested in the conditions under which she and her family live. ${ }^{49}$

46 'Over the Air-Mrs A. B. Speedie, Vice President Speaks of Equal Pay for Women', Housewife, August 1936, 6.

47 Ibid.

48 'Mrs. Watts Broadcasts to Members', Housewife, June 1936, 4.

49 'Broadcasts by Mrs. John Downing, Senior Vice-President', Housewife, March 1936, 8. 
Women, according to Downing, could not improve things on their own but rather needed to 'seek the assistance and co-operation of women likeminded, and thus a Society is formed of those who feel that union is power and strength'. ${ }^{50}$ The HA was this society.

The HA also used broadcasts to advocate particular issues, often relating to the prices of necessities. For example, in 1936 Speedie broadcast on the price of public transport fares and the dismal level of service. ${ }^{51}$ In 1937, the organising secretary, Rachael Robinson, broadcast on the price of bread, a longstanding issue for the HA, and outlined the organisation's advocacy of this issue on behalf of poorer members of society-that 'portion of the community least able to fight for itself, and to whom the price of bread is of very great importance. ${ }^{52}$ The HA, therefore, recognised that radio was a medium that could be used to communicate with housewives, publicly advocate for issues on their behalf and encourage collective action. In doing so, they demonstrated that radio was not only used as a medium for overtly feminist activism but also provided a platform for a range of women to increase their influence and adopt new methods of influence.

\section{Women's Radio Clubs}

Radio's ability to enable women to claim their voice as citizens in these years was not limited to relatively well-connected women giving talks and organising women's sessions. From the late 1920s, radio clubs began to be formed, which brought listeners together in real life to foster communities and perform charitable works, especially in response to the suffering caused by the Great Depression. These were associations of largely female members, who listened to the same daily radio program and would regularly meet in person to socialise and fundraise. The radio program was central to the activities of these clubs, as it provided a daily point of interaction for members. The activities of the clubs were arranged through the broadcasts, and the compere was often also the club president.

The Great Depression had a profound effect on Australia. Although unemployment figures from this era are significantly under-reported, at least one-fifth of wage and salary earners were out of work between 1930

50 Ibid.

51 'Broadcast by Mrs A. B. Speedie, Vice-President', Housewife, May 1936, 4.

52 'A Subject That Affects All Housewives-The Price of Bread: A Strongly Worded Protest through 3AW by Miss Rachael Robinson', Housewife, October 1936, 5. 
and 1934, and unemployment reached a high point of 30 per cent of union members in mid-1932. ${ }^{53}$ In 1932 , up to 1 million people, in a total workforce of 2 million, lacked stable full-time employment. ${ }^{54}$ While the economy began to recover by late 1933, it was only by the end of the decade that real domestic product per capita reached the same level as 1920-21. ${ }^{55}$ Although women's employment tended to be more stable than men's because female workers were concentrated in less exposed industries with lower wages, for many women, the loss of their husband's jobs placed considerable strain on their ability to manage their households and care for their families. ${ }^{56}$ Moreover, middle-class people keenly felt the loss of self-esteem that came with unemployment, and they did not have the support systems to draw on that were well established in working-class communities (although working-class families experienced poverty more acutely). ${ }^{57}$ Further, charity was strongly stigmatised, with people turning to charitable organisations only when they could not get assistance from friends and family. ${ }^{58}$ Unemployment drastically disrupted the routines of life, family relations and financial security.

Within this context, radio played an increasingly important role as a reliable source of entertainment and assistance. During this period, listeners were exhorted to 'tune out the gloom' by listening to their wireless. ${ }^{59}$ Speaking in an oral history interview in the 1970s, 'Sheila', a former $3 \mathrm{KZ}$ advertising scriptwriter, remembered that one of the functions of radio during the Great Depression was to help people. Radio programs that directly canvassed for support for destitute listeners were seen as a public service, while radio clubs were 'weapons against loneliness'. ${ }^{60}$ In this way, radio became a cohesive social force during the fractured years of the 1930s. As Sheila noted: 'Radio was one of the success stories of the Great Depression. ${ }^{61}$

53 Stuart Macintyre, The Oxford History of Australia, Volume 4 1901-1942: The Succeeding Age (Melbourne: Oxford University Press, 1986), 275.

54 Ibid.

55 Ibid., 286-87.

56 Ibid., 279.

57 Ibid., 278.

58 Ibid., 284.

59 Bridget Griffen-Foley, 'Modernity, Intimacy and Early Australian Commercial Radio', in Talking and Listening in the Age of Modernity: Essays on the History of Sound, ed. Joy Damousi and Desley Deacon (Canberra: ANU E Press, 2007), 123-32.

60 Wendy Lowenstein, Weevils in the Flour: An Oral Record of the 1930's Great Depression in Australia (Melbourne: Hyland House, 1978), 285-89.

61 Ibid., 288. 
Radio clubs were a key way in which many women dealt with the hardships imposed on them by the Great Depression, especially middleclass women who found a supportive social network over the airwaves. These clubs enabled radio station to foster intimate communities among their listeners. Stations set up clubs 'to enhance the industries' civic reputability, insinuate themselves in the lives of consumers, engender goodwill and facilitate tie-ins with business'. ${ }^{62}$ Through these clubs, radio became more than entertainment-it became a social movement, although it should not be forgotten that many of the clubs operated at least partly for commercial reasons, including facilitating tie-ins with local and national businesses. ${ }^{63}$ Nevertheless, the clubs allowed for personal contact with radio hosts and other listeners, which fostered a greater sense of intimacy among audiences.

While these clubs were certainly a result of the commercial radio industry's desire to craft intimacy and prove its legitimacy as an alternative to the $\mathrm{ABC}$, they also provide one of the clearest and most widespread examples of how women's citizenship was expanded through radio in the interwar years. Feminist conceptions of citizenship in the early twentieth century often centred on women's contribution to society through charitable and philanthropic works; their political enfranchisement was a recognition that they were already citizens in these ways. ${ }^{64}$ Radio provided them with a new way of performing these citizenship duties by communicating through the airwaves each day. These women conceptualised the role of radio as a social good that could bring others together and help them through times of struggle. Radio clubs around the country ran regular get-togethers for their members and numerous charity drives. Through these activities, they enacted a type of citizenship based on altruism and social justice.

The largest and most well-known radio club in the 1930s was the 2GB Happiness Club, run by Eunice Stelzer. This club promoted a 'brand of self-help, selflessness and sisterhood' that was of great comfort to listeners during the difficult years of the early 1930 s. ${ }^{65}$ Stelzer began the Happiness Club in 1929, when she was giving regular talks on Sydney commercial

62 Griffen-Foley, 'Modernity, Intimacy and Early Australian Commercial Radio', 127.

63 Bridget Griffen-Foley, Changing Stations: The Story of Australian Commercial Radio (Sydney: UNSW Press, 2009), 129.

64 Eva Cox, 'Feminism and Citizenship', in Rethinking Australian Citizenship, ed. Wayne Hudson and John Kane (Cambridge: Cambridge University Press, 2000), 57-58.

65 Griffen-Foley, 'Modernity, Intimacy and Early Australian Commercial Radio', 127. 
station $2 \mathrm{~GB}$. She noticed that she was receiving a large amount of mail from unhappy women who were lonely, neurotic or suffering in poverty. Stelzer attempted to answer these women via letter, but eventually felt that this was a poor way to communicate with them and believed that she could have a greater impact on their lives if she could talk to them personally. She arranged for an afternoon tea at the Sydney department store Angus and Coote's and advertised it during one of her radio talks. Stelzer expected perhaps a dozen people to turn up and was surprised and delighted when 250 crammed through the tearoom's doors. With such overwhelming attendance, Stelzer decided to turn the gathering into an official club, with the aim to make others happy, prevent loneliness and work for charity. ${ }^{66}$ The Happiness Club grew exponentially and spawned multiple branches across Sydney, Newcastle, Wollongong, the Central Coast, and even as far afield as London and New Zealand. By 1936, it had 11,000 members and 55 branches. ${ }^{67}$ It was a phenomenon that brought women together to perform their civic duty.

While there are no surviving recordings of Stelzer, analysis of radio magazines from the 1930s provides an indication of the importance of her radio speech to her public persona. It is clear from these sources that much of the appeal of the Happiness Club's radio sessions was Stelzer herself, who was revered by her listeners for her sincerity over the air: a 1936 article in Radio Pictorial announced that 'Sincerity is Keynote' in her sessions. ${ }^{68}$ Stelzer became a darling of the radio press, and her image confirmed her vocal persona as a kind and hardworking woman free of pretence. ${ }^{69}$ Yet, the importance of her vocal presence should not be underestimated; she broadcast daily at $2 \mathrm{pm}$ and used her broadcasts to make the Happiness Club central to its members' lives. The following quotation from Radio Pictorial illustrates the importance of the radio sessions to the club's activities:

The whole secret of the success of the Happiness Club is the amazing way in which Mrs. Stelzer manages to keep all the different branches united in a spirit of co-operation with herself-the chief president. This could never have been accomplished without broadcasting, for she used her session over $2 \mathrm{~GB}$ as a means of advertising all the various activities of the club's various

66 'Sincerity is Keynote', Radio Pictorial of Australia, 1 February 1936, 6.

67 Ibid.

68 Ibid.

69 Griffen-Foley, Changing Stations, 126. 
branches, and in that way secures the support of the listening public. For instance, busy person that she is, Mrs. Stelzer could not possibly attend all the functions that occur in the different branches, but, with the help of a wireless set installed in the hall where the function ... is being held, she can quite easily give an opening speech during her session, and she has, on a number of occasions, presented cheques by proxy through this means. ${ }^{70}$

Stelzer made innovative use of radio to run her growing network of Happiness Clubs. An article reported that when a call came through that a woman who had just given birth to twins was completely without babies' clothes, Stelzer immediately stopped reading out a recipe to send out a call for assistance for the woman. This was apparently just one of many such instances in which Stelzer was able to make use of the radio session, as 'without radio the Happiness Club could never have been able to function with such remarkable results' ${ }^{71}$ Through the club, Stelzer used radio as a technology that could improve women's lives by creating a sense of community and providing practical assistance in times of hardship. Further, through her media engagements, she developed and articulated a rhetoric of radio's role in improving society.

Hundreds of other clubs soon sprang up throughout the country, and these became a central aspect of women's radio in the 1930 s. The 3DB Woollies Friendship Club run by Iris Turnbull brought women together to knit warm items for donation to health centres and crèches. The club also held regular afternoon teas for its members. ${ }^{72}$ Radio clubs were also formed to promote women's sporting activities, such as the $2 \mathrm{CH}$ Women's League, formed in 1936 'for the physical advancement of the women of to-day'. ${ }^{73}$ The $3 \mathrm{AW}$ Women's Association held regular outings and sporting events, including hosting an ice skating club. Their motto was 'hold on to health and you will hold on to Youth' ${ }^{74}$

70 '2GB Happiness Club Activities: Brings More Revenue for Charities', Radio Pictorial of Australia, 2 March 1936, 12.

71 'Radio's Important Role', Radio Pictorial of Australia, 1 April 1936, 19.

72 'Women's Club Notes', Radio Times, 13 June 1936, 7.

73 'Australian Women's League', Radio Pictorial of Australia, 2 March 1936, 22.

74 'Women's Club Notes', 7. 


\section{Women Announcers}

Radio raised the profile of its women hosts, who became well-known personalities in their own right, unlike magazine writers who were often anonymous and did not have the same ability to project their individuality. ${ }^{75}$ In Australia during the 1930s, the personalities of announcers were constructed in the radio press in terms of their sincerity and empathy, which became sought after qualities for ideal female broadcasters. Their broadcasting expertise and position as respected public figures validated the place of women on the airwaves. Women announcers anticipated that radio could improve society and they worked to ensure that it did so.

The example of Perth ABC women's session presenter Dorothy Graham demonstrates the complexities of their position. Graham conducted the 6WF ABC Women's Session from 1929 until 1940. She attracted a large audience and established the $\mathrm{ABC}$ Women's Association, a radio club that organised a range of social and sporting activities. ${ }^{76}$ Her program focused on recipes, home hints and beauty tips, and Graham also wrote a weekly column for West Australian Wireless News and Musical World giving yet more recipes and home hints. ${ }^{77}$ The content of the session was, therefore, largely domestic in focus. But it is important to recognise that Graham also did much to promote radio as a necessity in women's lives that would broaden their outlook. She argued for the importance of radio in educating listeners in music and the importance of home happiness for good citizenship. ${ }^{78}$ In her session, she also broadcast talks by a range of women, including Dr Eleanor Stang, who gave weekly health talks in 1930 and, from 1936, Irene Greenwood's talks on Women in the International News, which were often overtly feminist and left wing, as will be explored in the next chapter. ${ }^{79}$ Thus, while Graham's program included a significant amount of domestic content, it should not be forgotten that it also educated women to be informed citizens by airing a range of topics.

75 Donna Halper, 'Speaking for Themselves: How Radio Brought Women into the Public Sphere', in Radio Cultures: The Sound Medium in American Life, ed. Michael C. Keith (New York: Peter Lang, 2008), 86-87.

76 Julie Lewis, On Air: The Story of Catherine King and the ABC Women's Session (Fremantle: Fremantle Arts Centre Press, 1979), 29.

77 See for example: Dorothy Graham, 'The Housewife's Corner', West Australian Wireless News and Musical World, 16 June 1930, 34.

78 Ibid.; Dorothy Graham, 'The Housewife's Corner', West Australian Wireless News and Musical World, 1 July 1930, 35.

79 Dorothy Graham, 'The Housewife's Corner', West Australian Wireless News and Musical World, 16 April 1930, 33; Lewis, On Air, 29. 
The women who became famous as women's session comperes in the 1930s were key to radio's redefinition of female citizenship, as they actively performed this new ideal on their shows every day. Although recordings of these women do not survive, analysis of radio periodicals from the time demonstrates that their broadcasts were discussed in a particular way and presented as offering something different to that of male announcers. Women announcers were described as employing sincerity and empathy in their broadcasts, and thus using the medium to help their listeners and society. This ideal of citizenship as performing one's civic duty with empathy needs to be understood in relation to the dominant ideologies of women's organisations in this era, many of which were agitating for significant change to women's position in society. Women comperes were also central figures in this task, as they modelled engaged citizenship through their broadcasts and directly addressed women in their homes.

Myra Dempsey was one announcer on Sydney commercial radio renowned for her genuineness and empathy. ${ }^{80}$ In her session, Smilin' Thru', she covered a diverse range of topics, from fashion, to theatre, sports and motor cars. ${ }^{81}$ She was presented as a 'forceful, dominating personality' with an 'absurdly soft heart that is always melting at the silly little sentimental things of life. ${ }^{82}$ In an interview with Radio Pictorial in 1937, Dempsey highlighted the importance of authenticity for women announcers, and noted that listeners 'can immediately detect sincerity in a voice'.$^{83}$ She was scathing in her assessment of men who criticised women announcers, arguing that they had never listened to a woman for more than five minutes and that their prejudice had absolutely no basis as a result. These criticisms were also ridiculous, she said, as plenty of women announcers had managed to keep their jobs, presumably in some part due to their ability to command an audience. She nominated sincerity as a key reason why women announcers were popular and successful:

It has been proved that the sincerity of the women on the air in Sydney has brought happiness and comfort and cheer into many people's lives. And believe me, it's not always realised just how the women are feeling themselves. No matter how tired or outof-sorts they may be, they know that if they can't be pleasant and

80 Bridget Griffen-Foley, 'The Gabblings of Gabba', Australian Book Review, no. 289, March 2007,

81 'Winner of Myra Dempsey's 2UW Competition', Radio Pictorial of Australia, 1 February 1936, 28.

82 'Smiling Thru' With Myra Dempsey', Radio Pictorial of Australia, October 1937, 23.

83 Ibid. 
cheerful they had better not broadcast at all. It's only their courage and sincerity that keeps them going in the face of so much adverse criticism. $^{84}$

In this statement, Dempsey presented the sincerity of women announcers as hard work that they performed for the betterment of society. As a result of their efforts, Dempsey argued, the public were loyal to these sincere women announcers, noting that her own listeners enthusiastically welcomed her back after a year-long absence from broadcasting. ${ }^{85}$

Dorothy Jordan was one of the first women announcers in Australia, starting on Sydney commercial station 2BL in 1925 before joining commercial station 2GB in the late 1920s. Before she became a broadcaster, Jordan was the women's representative on the 1921 Basic Wage Commission and was one of the first women to be appointed a justice of the peace in New South Wales. She took this commitment to civic duty into her broadcasting work. Jordan hosted the 2GB Women's Radio Service between $9 \mathrm{am}$ and 10am on weekday mornings, and believed that the success of her session was because she was 'always able to see the other person's point of view' and she therefore demonstrated great empathy to her listeners. ${ }^{86}$ In an interview with Radio Pictorial in 1936, Jordan nominated health talks as one of the most important benefits of radio, as they ensured that women had a much better standard of medical knowledge, which could help prevent the early death of children. ${ }^{87}$ Indeed, the impetus for her beginning her own women's session was the desire to reduce maternal and infant mortality, as she had lost her own three-year-old son to diphtheria and believed that this tragedy could have been averted had radio talks on children's illnesses been available at the time. ${ }^{88}$ Jordan fought against the perception that such talks were inappropriate for radio and was vindicated by the overwhelming response she received from her listeners. ${ }^{89}$ She also reportedly had expertise in psychology and health, and used her 'magical, mystical power' to bring 'healing and comfort to thousands of women daily'. ${ }^{90}$ Once again, Jordan articulated her own vision of radio's potential

86 'Mother and Daughter in Radio', Radio Pictorial of Australia, November 1935, 43.

87 Ibid.

88 Ibid.

89 'How Australia's Pioneer Woman Announcer Started', Australian Women's Weekly, 30 March 1935, 22.

90 '2GB - The Theosophical Broadcasting Station', Broadcast Year Book and Radio Listeners' Annual, 1934, 111. 
and used her platform as an announcer to provide a social service and improve the lives of her listeners. Women such as Dempsey and Jordan were motivated by their belief in the social role of broadcasting and worked hard in their positions.

Although women announcers primarily spoke to other women in their sessions, they did sometimes address men. Goodie Reeve was a longtime announcer who presented children's and women's sessions on 2GB. Reeve's appeal was her 'extraordinarily sympathetic nature', which she put down to her recovery from a life-threatening illness and subsequent desire to spread kindness in the world. ${ }^{11}$ In 1937, she began a unique session titled For Men Only, broadcast on 2GB on Saturday afternoons at $4 \mathrm{pm}$. In this session, Reeve responded to men's requests for advice about their personal issues - a format usually reserved for women's radio. Radio Pictorial reported in October 1937 that the session had secured jobs, clothing, shelter, and pen friends for men and their families. When asked about the significant responsibility she was undertaking in this session, Reeve responded:

I'm keenly alive to the responsibility of it, don't worry. Sometimes it nearly gets me down. Particularly when they say they are about to commit suicide. There are some I worry terribly about. Of course, I can't do much but I talk to them and try to help them in the most practical way I can. ${ }^{92}$

In this session, Reeve made use of a type of programming usually aimed at women listeners to create a space for men to explore their intimate lives and give voice to their suffering. This session highlighted the gendered social disorder of the 1930s; as Stuart Macintyre has noted, the performance of wage labour was central to Australian masculinity and an 'affirmation of [a man's] very identity', the loss of which led to a crisis of masculinity for many. ${ }^{93}$ It is especially notable that it was a woman who created and conducted such a session; it is clear that women could perform an important duty on radio through providing comfort and empathy to their listeners. In this program, Reeve performed active citizenship by working for the broader social good, and this included looking out for men's wellbeing in the difficult years of the 1930s.

91 'Miss Radio', 'For Men Only_and That's Why Women Listen!', Radio Pictorial of Australia, 1 October 1937, 7.

92 Ibid., 48.

93 Macintyre, The Oxford History of Australia, 276. 


\section{Conclusion}

The interwar years were a period that saw the rise of a particular type of woman citizen, whose commitment to civic duty emphasised collective empowerment and social good. This concept of citizenship was articulated and enacted by many women's organisations across the political spectrum during these years. At the same time, broadcasting on both commercial and public radio was viewed as a tool that could educate the modern citizen, and together these factors enabled the emergence of radio as a new space in which women could enact active citizenship and contribute to the public sphere, both collectively and as individuals. In this period, commercial radio provided greater opportunities for women to speak on air, and they founded women's clubs both to support local communities and promote local and national businesses. However, the public broadcaster also offered women's sessions, as the example of Dorothy Graham's session on the ABC's Perth station demonstrates.

During this period, a number of women identified radio as a technology that could help integrate women into the public sphere and improve their lives. These included feminists such as Linda Littlejohn and Jessie Street, women's organisations such as the Victorian Housewives' Association, as well as radio club comperes and announcers. Through their broadcasting these women helped to create a community among women and establish radio as a platform that could be used to advance women's position in society. As will be explained in the next chapter, this was further developed by women's broadcasts on international affairs during the 1930s-especially on the ABC. 
This text is taken from Sound Citizens: Australian Women Broadcasters Claim their Voice, 1923-1956, by Catherine Fisher, published 2021 by ANU Press, The Australian National University, Canberra, Australia.

doi.org/10.22459/SC.2021.01 